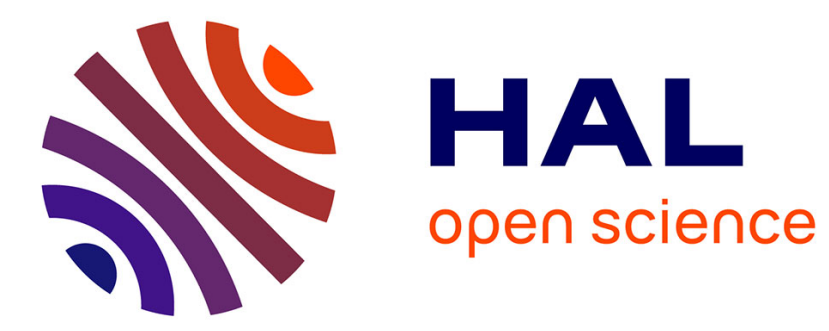

\title{
Organisation and formal activism: insights from the anarchist tradition
}

Federico Ferretti

\section{To cite this version:}

Federico Ferretti. Organisation and formal activism: insights from the anarchist tradition . International Journal of Sociology and Social Policy, 2016, 10.1108/IJSSP-11-2015-0127 . hal-01371300

\author{
HAL Id: hal-01371300 \\ https://hal.science/hal-01371300
}

Submitted on 25 Sep 2016

HAL is a multi-disciplinary open access archive for the deposit and dissemination of scientific research documents, whether they are published or not. The documents may come from teaching and research institutions in France or abroad, or from public or private research centers.
L'archive ouverte pluridisciplinaire HAL, est destinée au dépôt et à la diffusion de documents scientifiques de niveau recherche, publiés ou non, émanant des établissements d'enseignement et de recherche français ou étrangers, des laboratoires publics ou privés. 


\section{Organisation and formal activism: insights from the anarchist tradition}

Federico Ferretti

federico.ferretti@ucd.ie

\section{Abstract}

Elisée Reclus (1830-1905) argued that 'anarchy is the highest expression of order'. This assertion, clashing with the bourgeois interpretation of anarchy as chaos, perfectly captured the theories that were being elaborated by Reclus and other anarchist geographers including Pëtr Kropotkin (1842-1921). At the centre of these theories lay the conviction that societies organised around mutual aid and cooperation would be infinitely more rational and empowered than societies organised under the State and capitalism. Then, militants like Errico Malatesta (18531932) and Luigi Fabbri (1877-1935) advocated the need for formal anarchist organisation - to put in practice the principles of a horizontal and federalist society in daily life - and prepare the grounds for revolution. Acknowledging the importance of better understanding the past to inform the present, this paper first shows the link (generally overlooked by anarchist historiography) between Reclus's and Kropotkin's idea of order and Malatesta's and Fabbri's idea of organisation; then, it presents the model of anarchist organisation as a possible resource for present-day social movements, which often act as spontaneous networks of activism without a deep reflexion on organisational issues. According to the tradition of organisational communist anarchism, represented today by the International of Anarchist Federations, organisation is a key point, being not only a necessity, but the method for social transformation: without clarity on this, social struggles are likely to fall either in reformism either in Jacobinism. Finally, I show how present-day anarchist geographies can contribute to these points through their effort to prefigure new spaces for new societies.

Keywords: anarchist organisation; mutual aid; anarchist geographies; transnational anarchism; International of Anarchist Federations

"Organisation and formal activism: insights from the anarchist tradition", International Journal of Sociology and Social Policy, vol. 36, n. 11-12 (2006) [special number "Protest and activism (with)out organisation", edited by P. Wood and R. White], http://www.emeraldinsight.com/doi/pdfplus/10.1108/IJSSP-11-2015-0127 
'If it is true that organization creates leaders, if it is true that anarchists are unable to come together and arrive at an agreement without submitting themselves to an authority, this means that they are not yet very good anarchists, and before thinking of establishing an anarchist society within the world they must think of making themselves able to live anarchistically. The remedy does not lie in the abolition of organization but in the growing consciousness of each individual member' (Malatesta, 1897).

\section{Introduction: Activism and (in)formal organisation: re-asserting the ongoing relevance of anarchist tradition}

The paper will explore - and emphasize - the advantages of appealing to 'order within activism' from an unexpected radical tradition: anarchism. The uncoupling of order from anarchism has long been part of wider ignorance, propaganda and common misrepresentations about anarchism itself. In drawing attention to this misreading of anarchist praxis, and exploring what influential anarchist thinkers actually said about order, organisation and the question of violence/antiviolence, then important new insights and implications for an anarchist-inspired contemporary activism may be brought into being.

In 1851, Elisée Reclus (1830-1905) said that 'anarchy is the highest expression of order'. This assertion, clashing with the bourgeois interpretation of anarchy as a synonym of chaos, perfectly captured the theories that were being elaborated by Reclus and other anarchists of this time, including Pëtr Kropotkin (1842-1921) and Léon Metchnikoff (1838-1888). At the centre of these classical anarchist theories lay the conviction that societies organised around mutual aid and cooperation would be infinitely more rational and empowered than societies organised under the State and capitalism. It is of great concern therefore to observe how the historical praxis of anarchism, and the question of 'order' is unfamiliar to many scholar-activists discussing the new tendencies in anarchist movements. Such neglect is particularly worrying in terms of a lost dialogue with how anarchist views on 'order' may influence and inform new approaches to activism, both in the contemporary period, and in future.

"Organisation and formal activism: insights from the anarchist tradition", International Journal of Sociology and Social Policy, vol. 36, n. 11-12 (2006) [special number "Protest and activism (with)out organisation", edited by P. Wood and R. White], http://www.emeraldinsight.com/doi/pdfplus/10.1108/IJSSP-11-2015-0127 
Before continuing it is worthwhile offering some contextual reflection on why this uncoupling of order and anarchism has taken place, as well as confronting the fallacious assumption that the tradition of so called 'classical anarchism' has ended. Witness Castells conjecture that the sympathies of contemporary anarchists now lean towards 'loosely organized and largely selfmanaged patterns of mobilization and discourse', because organized anarchism 'did not survive the repression it suffered under both capitalism and communism' (Castells, 2005). Even authors sympathetic with anarchism have tended to mistakenly define anarchist organisational practices as essentially lacking - or actively refusing - permanent organisation. Indeed, for some, a fascination for the idea of 'dis-organisation' remains. This can be detected in Ferrell's (2012), use of the adjectives 'anarchic' and 'anarchist', or Curran and Gibson (2013:305), who have sought to distinguish between different approaches to anarchism, by contrasting "anarchist" from "anarchical" political praxis' for example. That is to say, 'between ideologically motivated, cardcarrying anarchists and anarchical forms of political praxis inspired by anarchist analyses and principles' (Gibson, 2013:336). Such distinctions remain deeply problematic, because not only do they seem to continue identifying anarchism on the grounds of what it is not, but they fail to advance a discursive space for 'anarchical' practices, and how these could inspire a further momentum for social transformation. However, as this paper seeks to assert, such pronouncements only hold true if all the organised traditions of anarchism are ignored.

One of my main aims therefore is to demonstrate that the distinctive characteristics of anarchist organization are not networking, spontaneity, and decentralization (even if decentralization is a necessary condition). Rather anarchist attitudes toward organisation are still adopted by the anarchist federations belonging to the International of Anarchist Federations (IFA/IAF)— drawing on the definition provided by Errico Malatesta, considering organisation as not only a necessary tool to coordinate collective efforts toward societal transformation, but also a way to experiment libertarian and egalitarian social relations in daily life in the context of a "patient work' (Turcato, 2015:128) towards anarchist goals. These traditions - asserting the importance of order, mutual aid and solidarity within an anarchist society - are still pervasive at the present moment. In short, a revaluation of historical tendencies in anarchism is long overdue, particularly in the context of order, activism and organisation.

"Organisation and formal activism: insights from the anarchist tradition", International Journal of Sociology and Social Policy, vol. 36, n. 11-12 (2006) [special number "Protest and activism (with)out organisation", edited by P. Wood and R. White], http://www.emeraldinsight.com/doi/pdfplus/10.1108/IJSSP-11-2015-0127 
Informal organisation is not - and never has been - a distinctive form of anarchist organisation. Indeed a fetishisation of informality has been recently contested as a non-libertarian principle by many anarchist organisations, as will be shown later with reference to the example of the Italian Anarchist Federation. In this critical appraisal it should also be recognised that that reticular organisation and informality are often presented as characteristic features of contemporary neoliberal economies, where decentralisation also plays a role in flexible capitalist accumulation (Castells, 2010; Harvey, 1989). In this sense, it has been provocatively suggested that neoanarchism and neo-liberalism share many features such as the adoption of horizontal and decentralised structures (Taylor, 2013:736). It is worth noting that claims for formal anarchist organisations do not contradict the spontaneous or 'autonomous, decentralized organization' (Day, 2005:27) characterising grassroots social movements. Organisational anarchists simply argue that the best way to engage with these movements and to play a role within them (not a leading one as in the Leninist idea, but an inspiring one) is having a publically visible and organised presence in the related social struggles.

This paper is composed of four sections: the first addresses the idea of anarchism as ordered society according to early anarchist geographers; the second analyses the tradition of organisational anarchism; the third presents some more recent outcomes of these debates; the fourth discusses the consistency of present-day anarchist geographies with this tradition and their insights for present struggles.

\section{Recognising the social order of Anarchy}

The statement highlighted at the beginning of this paper: "Anarchy is the highest expression of order' ${ }^{1}$ was written in 1851, in Reclus's first work Le Développement de la liberté dans le monde. Even though an organised anarchist movement did not exist until the 1870s (when Reclus was one of its founders), the young Reclus evoked a tradition inspired by both Pierre-Joseph Proudhon (1809-1865) and his idea of cooperation and solidarity among workers, which was then called Autogestion (a term which can be roughly translated as 'self-organisation') and the 1848

\footnotetext{
1 Amsterdam, International Institute of Social History, Elisée Reclus Papers, ARCH01170, manuscript Le Développement de la liberté dans le Monde, Montauban, 1851 [published in 1925 by Le Libertaire (28 août-2 oct.)] "Organisation and formal activism: insights from the anarchist tradition", International Journal of Sociology and Social Policy, vol. 36, n. 11-12 (2006) [special number "Protest and activism (with)out organisation", edited by P. Wood and R. White], http://www.emeraldinsight.com/doi/pdfplus/10.1108/IJSSP-11-2015-0127
} 
Revolutions, acknowledged as one of the founding moments for anarchist ideas (Prichard, 2013). In the 1870 s, the idea of anarchist organisation was put into practice in the context of the First International, after the separation between the General Council led by Marx and Engels, who sought to centralise the organisation, and the 'anti-authoritarian' sections by Switzerland, Spain, France, Italy, and United States, which met in 1872 in Saint-Imier (Switzerland) to inaugurate the 'Anti-authoritarian International' (Guillaume, 1905). In this context, one finds other statements identifying capitalism - and not anarchy—with themes of disorder. One of these came from the Geneva militant Charles Perron, cartographer of Reclus's New Universal Geography (Ferretti, 2014). In a pamphlet written for public education Perron argued: 'Ignorance, here is the organic social vice, the foremost cause of disorder! It is here that it is necessary to strike, and strike hard, because if we can make this cancer disappear, the truth, the final revolution will be accomplished' (1868:3). It is worth noting here that Perron, Reclus and Kropotkin, who are not considered by anarchist historiography as the most animated partisans of organisation, were also among the protagonists of the first anarchist organisation in history (the Fédération jurassienne). The Fédération jurassienne directly followed Bakunin's International Alliance for Socialist Democracy (Cerrito, 1973:31) in which Reclus also took part (Guillaume, 1905).

On the question of social order, the theory of mutual aid is a clear example of the commitment of anarchists to identify the grounds upon which anarchist society can work (Gould, 1997). Recent research has shown that the mutual aid theory, popularised by the famous book by Pyotr Kropotkin (1902), was the result of a collective elaboration by Reclus, Metchnikoff, and Kropotkin during their common work in Switzerland between the 1870s and the 1880s (Ferretti, 2011). In Kropotkin's paper 'The Coming Anarchy', which anticipated his later writings on mutual aid, we find the classical anarchist argument against the commonplace of anarchism as chaos, stating that the true chaos resides in capitalist society.

'[It has been said] that whenever there is no government there is disorder; and it implies, moreover, that order, due to a strong government and a strong police, is always beneficial. Both implications, however, are anything but proved. There is plenty of order (we should say, of harmony) in many bunches of human activity where the government, happily, does

"Organisation and formal activism: insights from the anarchist tradition", International Journal of Sociology and Social Policy, vol. 36, n. 11-12 (2006) [special number "Protest and activism (with)out organisation", edited by P. Wood and R. White], http://www.emeraldinsight.com/doi/pdfplus/10.1108/IJSSP-11-2015-0127 
not interfere ... As to the proverbial "order" which was once "restored at Warsaw" there are, I suppose, no two opinions about it' (Kropotkin, 1887:153).

In this sense, order and social harmony are considered to be built through cooperation; this implied also a political distance between the theorists of mutual aid and the so-called 'anarchistsindividualists' who started to be perceived in the anarchist movement, mainly the Frenchspeaking one, at the end of the 1880s and definitively in 1892-1894 with the so-called 'anarchist bombers'(Maitron, 1975). Many of these individualists denied explicitly the ideas of solidarity and even the basic principles of association. On the contrary, according to Kropotkin (1887: 157), within animal to human societies the habits of cooperation

'are a necessary condition for the welfare of the species in its struggle for life, co-operation of individuals being a much more important factor in the struggle for the preservation of the species than the so-much-spoken-of physical struggle between individuals for the means of existence. The "fittest" in the organic world are those who grow accustomed to life in society, and life in society necessarily implies moral habits. As to mankind, it has, during its long existence, developed in its midst a nucleus of social habits, of moral habits, which cannot disappear as long as human societies exist'

Another political implication of the idea of mutual aid was the belief in evolution as one of the processes which would help encourage societies to move toward more libertarian and egalitarian horizons, expressed in texts such as Evolution et Révolution by Reclus (1891) and 'Revolution and Evolution' by Metchnikoff. This also meant that anarchist revolution didn't draw on a unique (Jacobin) violent clash breaking the bourgeois society, but on progressive and gradual liberation processes based on increasing individual and collective consciousness. In his paper, published in the Contemporary Review, Metchnikoff_dissatisfied by the narrow definitions of sociology given by both August Comte and Herbert Spencer-insisted that the premises of social cooperation were observable both in the early human societies and in the groups of animals. 'Natural science teaches us that association is the law of every existence. What we call society in common speech is only a particular case of that general law' (Metchnikoff, 1886:415). This

"Organisation and formal activism: insights from the anarchist tradition", International Journal of Sociology and Social Policy, vol. 36, n. 11-12 (2006) [special number "Protest and activism (with)out organisation", edited by P. Wood and R. White], http://www.emeraldinsight.com/doi/pdfplus/10.1108/IJSSP-11-2015-0127 
theory could accommodate Darwinian evolutionism while at the same time asserting cooperation (rather than competition) as the main factor of evolution in human societies. In his main work, $L a$ civilisation et les grands fleuves historiques, Metchnikoff argued that the highest level of social evolution would be a society where cooperation is not imposed, but applied spontaneously in every aspect of social life, that is, the anarchist society. 'So, the sociological progress is in inverse relation to the degree of coercion, constriction and authority deployed, and in direct relation to the role of will, freedom, anarchy' (Metchnikoff, 1889:89).

Metchnikoff is also a little-known figure among anarchists, but his research was very important to Reclus and Kropotkin, and his works, circulating among the anarchist militants of that time, influenced some of their conceptions. In a letter to Fabbri, Malatesta endorsed La civilisation et les grands fleuves historiques, indicating that, even though he didn't personally know Metchnikoff, 'I read the book at the request of Kropotkin, later I read it again and always found it most interesting'. ${ }^{2}$ This document is important because, even though traditional anarchist historiography has seen some opposition between the 'educationism' of Reclus and Kropotkin and the revolutionary 'voluntarism' of Malatesta (Berti, 2003), it should be noted that, in the spaces between these two interpretations, there are more points in common than generally considered, particularly regarding their shared challenge to the aforementioned uncoupling of anarchy and order.

\section{Struggling against 'bourgeois influences': Errico Malatesta and Luigi Fabbri}

Errico Malatesta, one of the most famous anarchists of his time, criticised Kropotkin's idea of anarchy as a science, considering that it could lead towards an excessive fatalism and stating the necessity to focus more on the action's practical needs than on theory. Malatesta's method was then deemed a voluntarist one: this means that anarchists need to do a long and 'patient work' to put the bases for a future social revolution (Turcato, 2015:128). Nevertheless, there was a clear continuity between the 'educationism' by Reclus and Kropotkin and the 'voluntarism' by Malatesta and his closest friend and collaborator, Luigi Fabbri, the latter strongly committed to

\footnotetext{
${ }^{2}$ IISH, Luigi Fabbri Papers, 112, E. Malatesta to Luigi Fabbri, 7 November 1927.

"Organisation and formal activism: insights from the anarchist tradition", International Journal of Sociology and Social Policy, vol. 36, n. 11-12 (2006) [special number "Protest and activism (with)out organisation", edited by P. Wood and R. White], http://www.emeraldinsight.com/doi/pdfplus/10.1108/IJSSP-11-2015-0127
} 
the political and scientific work by Reclus. In particular, if the anarchists inspired by Malatesta considered the ideas of education and evolution not enough for the final revolutionary outcome, nonetheless they did not deny their importance for social transformation. It is worth noting that radicalizing pedagogy is one of the challenges for today social movements and an object of recent contributions from anarchist geographies (see Springer et al., 2016).

Malatesta and Fabbri were both exponents of the anarchist transnational networks, which are increasingly interesting to present-day scholarship as a characteristic of historical anarchism (Bantman and Altena, 2015; Hirsch and Van Der Walt, 2010). As shown by Davide Turcato (2007), Italian/speaking militants played a very important role in these networks, mainly because they, more than others, circulated throughout the world as political exiles, economic migrants, or committed international propagandists. One of the hubs of transnational anarchist communities of exiles and migrants at the time was the city of London, where both Malatesta and Kropotkin lived for many years. There, Malatesta started his struggle for organizing anarchists with the clear aim to one day bring this organisation to Italy, when the movement was then harshly repressed by the government. According to Pietro Di Paola, these efforts took place around periodicals such as L'Associazione. 'Its political aims were ambitious: the reorganisation of the anarchist movement and the constitution of an international socialist-anarchist revolutionary party with a common platform; a party whose unity and discipline derived not from leaders or official deliberations but from co-operative action, consciousness and the sharing of means and ends' (Di Paola, 2013:79).

According to Malatesta, the lack of formal organisation which characterized the anarchist movement in the 1880s and 1890s was not the result of a conscious strategy as believed even by many anarchists, but the (evil) result of the dissolution of the First International, which had lost its contacts with workers. Nevertheless, Malatesta deemed organisation a strategic point for anarchism. 'Organization which is, after all, only the practice of cooperation and solidarity, is a natural and necessary condition of social life; it is an inescapable fact which forces itself on everybody, as much on human society in general as on any group of people who are working towards a common objective' (Malatesta, 1897).

"Organisation and formal activism: insights from the anarchist tradition", International Journal of Sociology and Social Policy, vol. 36, n. 11-12 (2006) [special number "Protest and activism (with)out organisation", edited by P. Wood and R. White], http://www.emeraldinsight.com/doi/pdfplus/10.1108/IJSSP-11-2015-0127 
In this context, organisation is presented as a necessity for social struggle and social transformation. 'The age-long oppression of the masses by a small privileged group has always been the result of the inability of the oppressed to agree among themselves to organize with others for production, for enjoyment and for the possible needs of defence against whoever might wish to exploit and oppress them. Anarchism exists to remedy this state of affairs' (Malatesta, 1897). However, organisation is also the condition to build in present society embryos of the future one and to guarantee to all associated the equality and freedom which disorganisation and informality are not able to grant. The basis of the proposed anarchist organisation was federalism. This followed the federalist tradition of anarchism by Proudhon, Bakunin, and Reclus, as well as the example of the Anti-authoritarian Federation's sections.

'The groups, the federation of groups, the federations of federations, meetings, congresses, correspondence committees and so on. But this also must be done freely, in such a way as not to restrict the thought and the initiative of individual members, ... for an anarchist organization, congresses-in spite of all the disadvantages from which they suffer as representative bodies - are free from authoritarianism in any shape or form because they do not legislate and do not impose their deliberations on others' (Malatesta, 1897).

Working groups such as the commission of correspondence should be devoid of directive powers but should only work as technical supports, building organisational practices in coherence with the kind of society that anarchists want to build. The coherence between means and ends was always one of Malatesta's key points; in this sense, anarchists shouldn't lead, but advice: 'We anarchists do not want to emancipate the people; we want the people to emancipate themselves. We do not believe in the good that comes from above and imposed by force' (Malatesta, 1897). According to Malatesta, where individuals and groups are not organised with assemblies and formal mandates, mechanisms of power are necessarily reproduced within disorganisation and informality. Malatesta used the example of some militant journals "whose pages are closed to all whose ideas, style or simply person have the misfortune to be unwelcome in the eyes of the editors.... The situation would be different if these newspapers belonged to all, instead of being the personal property of this or that individual' (Malatesta, 1907). In his critique of dis-

"Organisation and formal activism: insights from the anarchist tradition", International Journal of Sociology and Social Policy, vol. 36, n. 11-12 (2006) [special number "Protest and activism (with)out organisation", edited by P. Wood and R. White], http://www.emeraldinsight.com/doi/pdfplus/10.1108/IJSSP-11-2015-0127 
organisation, Malatesta argued that power can be reproduced in a wide range of ways at the micro-scale, as Michel Foucault similarly argued much later: on this point, Brian Morris (2014) has recently shown how mainstream poststructuralist critiques of power generally lack originality if compared to the rich (and neglected) anarchist tradition I am addressing here.

Malatesta's efforts were supported by Luigi Fabbri, the protagonist of the federation process by Italian anarchists started in 1904 in the region of Rome and leading to the constitution, in 1920, of the Italian Anarchist Union (Unione Anarchica Italiana - UAI). This process was defined as a 'struggle' because the aggressive opposition that it found by anti-organisational militants and individualists. Individualism reached strength and notoriety due to the French bombings of 18921894 and also owed to the introduction in the anarchist field of amoral and antisocial tendencies inspired by authors such as Stirner and Nietzsche, considered by social anarchists as extraneous to the movements' roots, and philosophically strongly challenged by Kropotkin (Kinna, 2016).

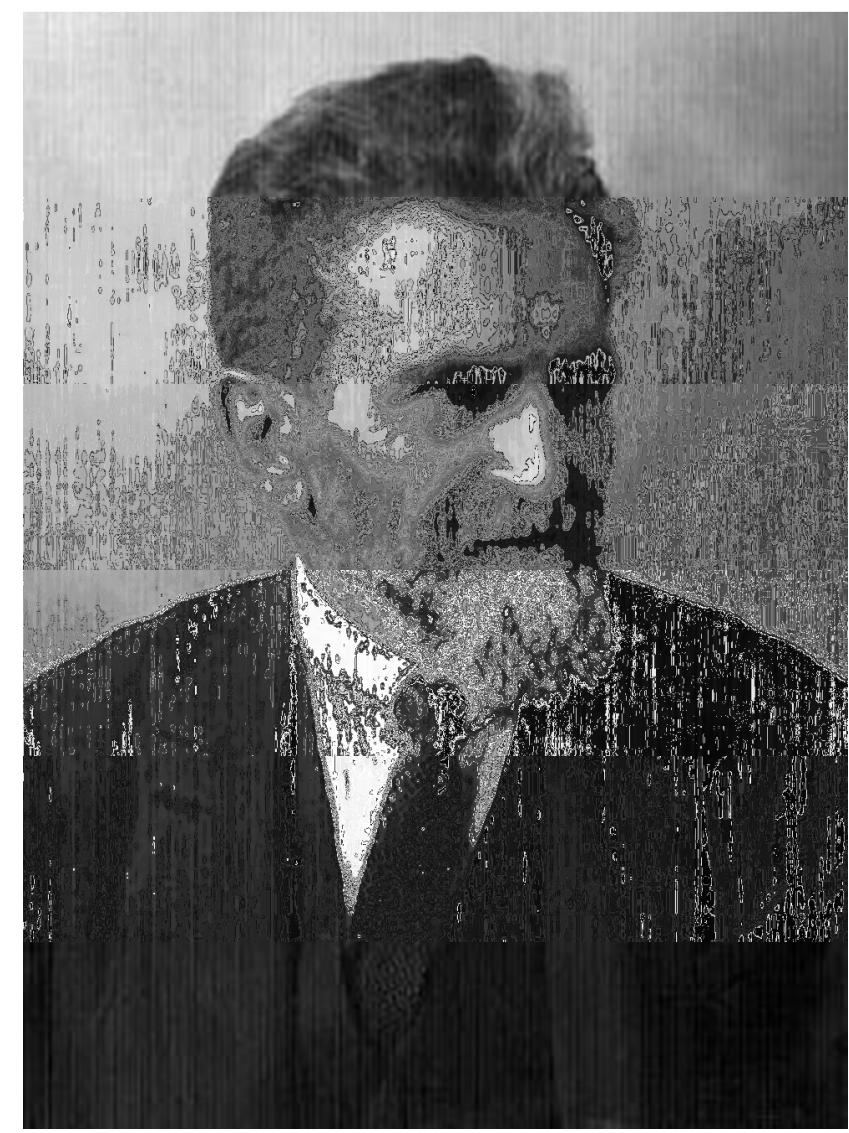

Fig. 1 - Errico Malatesta (1853-1932)

"Organisation and formal activism: insights from the anarchist tradition", International Journal of Sociology and Social Policy, vol. 36, n. 11-12 (2006) [special number "Protest and activism (with)out organisation", edited by P. Wood and R. White], http://www.emeraldinsight.com/doi/pdfplus/10.1108/IJSSP-11-2015-0127 


\section{Organisation and anti-violence}

So, the struggle for organisation was also the struggle against individualists and 'bombists', who did everything they could to boycott this work. This included shooting Malatesta in 1899 during a meeting, which only wounded the Italian anarchist (Turcato, 2015:190). In Malatesta's biography, Fabbri argued that having fought, and finally won, this battle for persuading anarchists to organize themselves (strictly linked to his critique of revolutionary violence as I explain below) was one of the best reasons for the elderly Malatesta to be proud. In this book, Fabbri argued that if anarchism starts from the rights of the individual, a declared 'individualism' was relatively late in anarchist tradition. 'It appeared around 1890; before, there were only antiorganisational tendencies, among which gradually emerged explicit individualist tendencies' (Fabbri, 1951:177). Thus, Fabbri argued that to get organisation it was necessary to contrast the individualistic tendencies, which he considered as bourgeois influences on anarchism. Trained in a humanistic and solidarist culture, Fabbri couldn't conceive of the violent propaganda of some individualists practicing 'egoism, theft . . . hate and disdain for losers' (Ibid.:178). Fabbri's argument was that this did not belong to anarchist principles, but that 'many people accepted as anarchist ideas all or a great deal of what the bourgeois invented against anarchism' (Manfredonia, 1998:XIII), that is to say, 'bourgeoisie exercised an extraordinary influence on anarchism, when it assumed the task to do anarchist propaganda' (Fabbri, 1998:19). The implication here is that when people read in the mainstream press that anarchists were amoral, violent, and opposed to organization, those who had these characteristics began to consider themselves as anarchists. In bourgeois milieus, there was also some aesthetic praising of the indiscriminate dynamite attacks of 1892-1894, as 'artists and dandies sympathised for the bombers' (Manfredonia, 1998:XI). Thus, according to Fabbri, 'bourgeois literature, which found in anarchism a pretext for violent aesthetics, contributed to diffuse among some anarchists an individualist and anti-social mentality' (Fabbri, 1998:16). On an amusing note, Fabbri recalled his own experiences as a political prisoner in Southern Italy, where some prisoners associated with the Mafia cheered anarchists who were detained, believing that Anarchy was the name of a powerful criminal organisation, thus 'worthy to be allied with their Honoured Society' (Ibid.:21). Fabbri shared Malatesta's critique of violence as a revolutionary means. This didn't imply an absolute non-violence, because defensive violence was considered a last resort in case of

"Organisation and formal activism: insights from the anarchist tradition", International Journal of Sociology and Social Policy, vol. 36, n. 11-12 (2006) [special number "Protest and activism (with)out organisation", edited by P. Wood and R. White], http://www.emeraldinsight.com/doi/pdfplus/10.1108/IJSSP-11-2015-0127 
repression, then applied by Italian anarchists, for instance in the resistance against fascism (Rossi, 2011). Nevertheless, they deemed violence the contrary of anarchy, which means 'love' (Fabbri, 1998:49). Consequently, 'violence must be used the least possible, and in any case only as a defensive resort, never as an offensive' (Ibid.:52). In this sense, Fabbri's critique concerned as well the verbal violence of some journals aiming to 'scare the bourgeois', promising flames, death, and dynamite, a language which he considered as useless and misleading.

The direct opposition between the couple of individualism and violence, and the ideas of organisation and solidarity appears clearly in what has been called 'a gradualist view of anarchy; the more people will embrace that sentiment and that value, the more broadly anarchy will be realized' (Turcato, 2014:3). According to Malatesta and Fabbri, partial conquests in social struggles, like those obtained by trade-unionism, didn't imply the forgetting of the final revolution as other anarchists stated, but could be useful as revolutionary training, if done with libertarian methods. This seems not so far from Reclus's idea that evolution and revolution are not contrasting terms, but two different speeds in the same social process (Reclus, 1891); it is also worth noting that Fabbri, and his daughter Luce (1908-2000), were the most important Italian translators and scholars of Reclus in the first half of the $20^{\text {th }}$ century (Ferretti, 2016).

Through Il Pensiero, Fabbri published his reports on 'Anarchist organisation' (L'organizzazione anarchica) and 'Workers' organisation and anarchy' (L'organizzazione operaia e l'anarchia) which he presented in the 1907 anarchist international congress in Amsterdam, when the issues of anarchist organisation and its links with revolutionary syndicalism were debated. Even though the practical proposals of the participants were different, what stood clear in this congress were the links between social anarchism, workers' struggles, and organisational issues. According to Fabbri, the individualism attributed to anarchism by its enemies contributed to lead some anarchists 'to deny the socialist principle of anarchism' (Fabbri, 1975:2). It was the occasion to state which organisation models anarchists should avoid, namely those of 'both Catholic church and Marxist church' (Ibid.: 3). In his report on anarchist organisation, Fabbri presented it as a strategic and central principle. 'One says that organisation is a mean and not an end; this is a mistake . . . the principle of organisation is one of the basic foundations of anarchist thought'

"Organisation and formal activism: insights from the anarchist tradition", International Journal of Sociology and Social Policy, vol. 36, n. 11-12 (2006) [special number "Protest and activism (with)out organisation", edited by P. Wood and R. White], http://www.emeraldinsight.com/doi/pdfplus/10.1108/IJSSP-11-2015-0127 
(Fabbri, 1907: 3). Thus, organisation was not a mere practical option, but the necessary method to apply for being all free and equal, experimenting new social relationships in daily life, and putting theory into practice. Fabbri presented it, ironically, as a specific form of "propaganda by the deed'. 'As the best propaganda is done by the example, we try to organise ourselves, to build groups, to federate them ... doing thus propaganda by the deed' (Ibid.:4, 6).

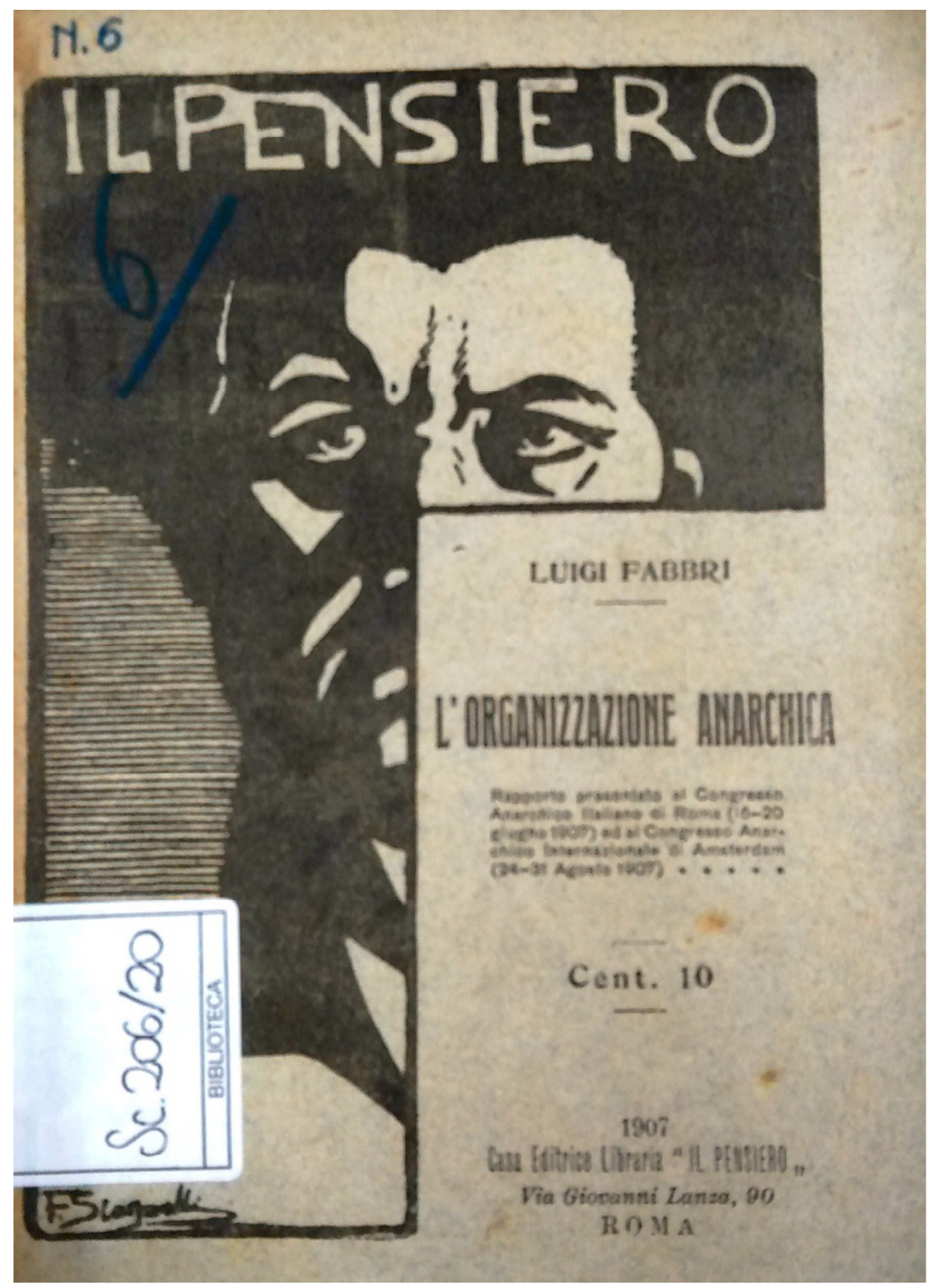

Fig. 2 - Fabbri, 1907

"Organisation and formal activism: insights from the anarchist tradition", International Journal of Sociology and Social Policy, vol. 36, n. 11-12 (2006) [special number "Protest and activism (with)out organisation", edited by P. Wood and R. White], http://www.emeraldinsight.com/doi/pdfplus/10.1108/IJSSP-11-2015-0127 
Fabbri's main argument was that the alternatives to formal organisation led to authoritarian developments, because even in a hypothetical future freed society, 'without anarchist organisational tools, the risk is that necessity leads people to re-adopt the authoritarian ones' (Ibid.:12). Fabbri argued that non-organised anarchists were 'those who are organised without knowing it and believe to be more autonomous than others' (Ibid.:19), because in informality and dis-organisation a most clever and prestigious person (or group) can centralise things performing an invisible organisation in which militants 'are unconsciously organised by the speaker, by the agitator or by the journal' (Ibid.:19). On the contrary, if they are formally organised, 'they can oppose a better resistance to the influence of the comrades more intelligent, more clever, more active' (Ibid.:20). Finally, if a formalized anarchist organisation was not possible, 'then it would be impossible to realize anarchy' (Ibid.:29).

It is worth stressing that Fabbri, at the end of his report, acknowledged the importance of Kropotkin and Reclus in establishing the principle of cooperation, association and mutual aid as a basis of his own organisational anarchism.

'Elie Reclus [Elisée's brother] found among the "primitives" several examples of libertarian groups, even if they don't live in full anarchy; Pyotr Kropotkin studied libertarian associations among animals, among "primitives", among the artisans in the medieval communes. Kropotkin and Elisée Reclus show how, also in present society, there are strong tendencies towards communism and anarchy, by presenting numerous examples of commercial, industrial, beneficence, scientific or artistic associations which are anarchist in their internal organisation, even if they have no anarchist aims. If this possibility is acknowledged for non-anarchist individuals, associated for bourgeois ends, why should we deny the possibility for us to be associated on libertarian bases?' (Ibid:31-32).

All along the $20^{\text {th }}$ century, authors like Fabbri and Malatesta were most influential in debates on anarchist organisation, which took place during the antifascist resistance and within the anarchist federations constituted in its aftermath, founding the IAF/IFA in a very significant date, 1968.

"Organisation and formal activism: insights from the anarchist tradition", International Journal of Sociology and Social Policy, vol. 36, n. 11-12 (2006) [special number "Protest and activism (with)out organisation", edited by P. Wood and R. White], http://www.emeraldinsight.com/doi/pdfplus/10.1108/IJSSP-11-2015-0127 


\section{Synthesis, informalism and international federation processes}

Anarchist organisation is strictly linked to the idea of federalism and strongly based on territorial groups and federations, without the need for recognizing political and administrative boundaries. A key example is the Spanish Movimento Libertario, whose biggest components-the National Work Confederation (CNT) and the Iberian Anarchist Federation (FAI)—realized, during the Spanish war of 1936-1939, a social revolution in regions such as Catalonia and Aragon which put into practice the anarchist geographers' ideas of decentralism as showed by Myrna Breitbart (1978). The basic forms of social life, in these communities, corresponded to the organisational scales of workers' unions and anarchist groups, established by the declaration of anarchist communism (Comunismo libertario) approved by the 1936 CNT Congress held in Zaragoza: 'The individual, the group, the federation' (Peirats 1951). This was clearly consistent with the traditional formula endorsed by Fabbri: 'Free individual in the group, free group in the federation, free federation in the International, as one said since Bakunin's times' (Fabbri, 1951:205). This also recalls Simon Springer's statement that 'scale is not synonymous with hierarchy' (Springer, 2014:410) as the geographical patterns of Spanish collectivization assumed clearly different levels of scale in the organization of production and consumption, without a subordination of the local levels to the central ones (Breitbart, 1978).

After the storms of Fascism, Stalinism, and the Second World War, which devastated the European anarchist movements, one of the most interesting experiences in post-war reorganisation was the Italian Anarchist Federation (Federazione Anarchica Italiana - FAI), direct heir of the UAI. Founded in Carrara in 1945 after a strong commitment by its militants in partisan resistance all over Italy (Rossi, 1981), the FAI adopted the Anarchist Program by Errico Malatesta and a Pact of Alliance on the model of the UAI. Its organisational principle is called the 'synthesis', referring to a debate which took place in the inter-war period among French and exiled Russian and Italian anarchists on the Platform of organisation proposed by the Ukrainian militants Pyotr Archinov and Nestor Makhno. They argued, after their defeat by the Bolsheviks in Russia, that anarchists should adopt a more centralised organisation to be more efficient in the

"Organisation and formal activism: insights from the anarchist tradition", International Journal of Sociology and Social Policy, vol. 36, n. 11-12 (2006) [special number "Protest and activism (with)out organisation", edited by P. Wood and R. White], http://www.emeraldinsight.com/doi/pdfplus/10.1108/IJSSP-11-2015-0127 
moment of hard struggles. The majority of international (and organisational) anarchists, including Fabbri and Malatesta, refused this proposal. According to Fabbri, the principle of anarchist organisation should be 'an inclusive and not excluding one' (Cerrito, 1973:316). In this sense, he stressed that in the UAI, the cooperation between different tendencies, in particular between different approaches to revolutionary syndicalism, was allowed by the principle of the 'synthesis' (Ibid.:319). This means that different theoretical positions could co-exist in an anarchist federation, when the basic operational aims (in the case of 1920 UAI, making the revolution as soon as possible) were shared. This also implies that decision making is not based on the principle of majority, and not even necessarily on that of unanimity; the key idea is that an eventual majority should not have powers for compelling the minority to accept its deliberations, thus every decision only engages those who freely adopt it. Malatesta criticised the Platform for its proposal to institute an executive committee (and not a simple commission of correspondence devoid of executive powers) and to adopt the principle of majority, arguing that 'Anarchists do not admit the power of majority, called democracy, as they do not admit the power of some, called aristocracy, or the power of one, called autocracy' (Ibid.:333). As a result, the 'synthesis' has become the general definition of the organisations inspired by Malatesta's work.

An important FAI's outcome was its initiative towards an International of Anarchist Federations, finally constituted in the 1968 international anarchist congress held in Carrara (Zani, 2008). The IAF/IFA includes today federations in different continents. Its Commission of Correspondence was entrusted, for the first years, to the prestigious Italian (transnational) militant Umberto Marzocchi (1900-1986), inspired as well by Malatesta and Fabbri (Sacchetti, 2005).

Some events from the Italian political life of the past 10-15 years highlight the difference between this kind of anarchist organisation and more informal approaches. In the 1990s, some exponents of the area called 'anarchist-insurrectionist', a network violently opposed to all that is communist, social, and organised in anarchism, started to talk about an 'informal organisation'. In December 2003, a rudimentary bomb was sent in a post packet addressed to the house of politician Romano Prodi, then president of the European Commission, in Bologna, and exploded without injuring anyone. Nevertheless, the event had a huge echo, and a claim of responsibility,

"Organisation and formal activism: insights from the anarchist tradition", International Journal of Sociology and Social Policy, vol. 36, n. 11-12 (2006) [special number "Protest and activism (with)out organisation", edited by P. Wood and R. White], http://www.emeraldinsight.com/doi/pdfplus/10.1108/IJSSP-11-2015-0127 
re-launched by all national and international medias, was signed by one Informal Anarchist Federation (Federazione Anarchica Informale - FAI), a phantom organisation which took provocatively the acronym of the Federazione Anarchica Italiana - FAI. This created not only confusion about the public image of anarchism in Italy, but also risked exposure of well-known militants belonging to groups doing public activities under the acronym FAI. The Italian Anarchist Federation thus had to respond publicly. The task of speaking with national press is generally committed to the Commission of Correspondence (which was then entrusted to the Federation of Reggio Emilia) whose members at that time wrote a public note, mentioned by several national newspapers that also interviewed them. This text is critical to understanding the evils of informalism for anarchist organisation and the persistent links between organisational issues and the problem of violence. In the following days similar packets arrived at public offices, the bombs sometimes wounding ordinary people (including porters and secretaries) and thus instigating the random violence against which social anarchists have raged since the $19^{\text {th }}$ century. It is also worth noting that the real existence of this 'informal federation' was never proved, thus the suspicion that all this could have been a provocation by some police or institution is still considered a possibility among militants.

The $C d C$ (Commission of Correspondence) stated then: '1. We denounce the infamous fact of attributing this act to an acronym which alludes to the FAI - Federazione Anarchica Italiana: the one who calls the attention of state's repression on a group of comrades is a policeman or his collaborator; 2. We confirm the tradition of anarchist organization as configured in the 1872 Saint-Imier Congress and in the deliberations by the UAI in 1920 and the FAI in 1945: our organization has nothing to do with informality, because for us the clearness and collectiveness of mandates are the only guarantee to make decisions according to an anarchist method; 3 . We reiterate our condemnation of bombs, bomb-packets and all devices which can strike randomly and serve, by way of consequence, the logics of provocation and criminalization of dissent in a period when the anarchists are among the protagonists of social struggles, strikes and anti-war initiatives; 4. We confirm that the struggles of the women and men participating in our federation are publically deployed in manifestations, in our engagement for autonomous syndicalism, in grassroots movements, in the anarchist clubs that we opened publically in dozens of cities, in our

"Organisation and formal activism: insights from the anarchist tradition", International Journal of Sociology and Social Policy, vol. 36, n. 11-12 (2006) [special number "Protest and activism (with)out organisation", edited by P. Wood and R. White], http://www.emeraldinsight.com/doi/pdfplus/10.1108/IJSSP-11-2015-0127 
open opposition to the logics of domination and to all state's terrorisms, and in our commitment to build a society of equality and freedom' (CdC-FAI, 2003). The CdC text was endorsed, a few weeks later, by the FAI national assembly, which published a longer document along the same lines, with the ironic title 'Anarchy is a priority, albeit not by mail' (L'anarchia é prioritaria, ma non si fa per posta) (Il convegno nazionale, 2004).

\section{Toward an anarchist organization of society and space? A focus on Anarchist Geography}

The main contribution of this paper within this Special Issue is to emphasise that the idea of a public and formalized anarchist organisation is highly consistent with the claims of key anarchists. Indeed its success enables the very possibility of an ordered anarchist society (which itself demands understanding as a highly geographical phenomenon). Thus - both historically and in the present moment - questions relating to the prefigurative spatial and territorial politics (and praxis) of anarchist individuals, groups and federations are central issues among anarchist organizers. I have argued that the question of formal organisation is a central one for anarchism and for its spatiality, and that it is consistent with Reclus's and Kropotkin's original idea of anarchism as social order. To understand the role played by spaces and places for anarchist organisation, it is worth considering not only the tradition of early anarchist geographers, but also the present literature rediscovering anarchist geographies. Springer argues that 'recognizing specific contexts of public space requires understanding that any social organization is both the outcome of the "local" politics of the street and their relational geographies to the wider power geometries of "global" space' (Springer, 2011: 541). Spaces and social organisation are linked to the opposition of a central authority principle, as exposed by Springer, who argues that 'anarchism opposes all systems of rule or forms of -archy (i.e. hierarchy, patriarchy, monarchy, oligarchy, anthroparchy, etc.) and is instead premised upon co-operative and egalitarian forms of social, political, and economic organization, where ever-evolving and autonomous spatialities may flourish' (Springer, 2012: 1606). Decentralisation, according to Springer, 'has been at the heart of radical geographical ideas for a very long time' (Springer, 2014: 405). Another important point in common between anarchist geographies and anarchist organizational practices is the idea of place-based prefigurative politics: according to Anthony Ince (2012: 162), 'rather than

"Organisation and formal activism: insights from the anarchist tradition", International Journal of Sociology and Social Policy, vol. 36, n. 11-12 (2006) [special number "Protest and activism (with)out organisation", edited by P. Wood and R. White], http://www.emeraldinsight.com/doi/pdfplus/10.1108/IJSSP-11-2015-0127 
believing that it is possible to use authoritarian or undemocratic means to create a free and equal society, anarchists have developed ways of embedding the political principles of an envisioned anarchist society into the ways they organise in the here-and-now . . . such as co-operative cultural and productive enterprises, libertarian schooling and member-run anarchist unions and tenants' groups'.

This idea of anarchy as a condition for free organisation without state and coercion was then stated on geographical bases. Reclus and Metchnikoff, for instance, addressed the history of the 'fluvial civilisation' of the Nile basin, arguing that only a dense and well-organized population could realize the managing of canals and floods. Metchnikoff, quoting the correspondent passages of Reclus's New Universal Geography, argued that the strong association needed to maintain channels, to periodically clear lands, and to seed after every flood could either be imposed upon individuals or freely adopted by association; human societies were before their first choices between anarchy and despotism. 'Either be all associated and equal in right, either be all the slaves of a master' (Metchnikoff, 1889: 227).

The argument by Kropotkin and Reclus that mutual aid is already present in many parts of capitalist society has been rescued and developed from the standpoint of economic geography, addressing 'the complex and multiple ways in which people in the "advanced economies" organise themselves to undertake regular material and social tasks" (White, 2009: 469). According to White and Colin Williams (2012: 1627), "many of these practices are ideologically orientated toward anarchist-based visions of work and organization'. Thus, the idea of social organisation as a possible basis for more conscious political outcomes is still debated in recent literature on geography and anarchism. As Colin Ward stated, referring to the anarchist tradition, 'an anarchist society, which organises itself without authority, is always in existence, like a seed beneath the snow, buried under the weight of the state and its bureaucracy, capitalism and its waste, privilege and its injustices, nationalism and its suicidal loyalties, relations differences and their superstitious separatism' (Ward, 1982: 14).

"Organisation and formal activism: insights from the anarchist tradition", International Journal of Sociology and Social Policy, vol. 36, n. 11-12 (2006) [special number "Protest and activism (with)out organisation", edited by P. Wood and R. White], http://www.emeraldinsight.com/doi/pdfplus/10.1108/IJSSP-11-2015-0127 


\section{Conclusion}

The question of anarchist organisation invites a complex response. Anarchism is firstly an attempt to build a libertarian and egalitarian society through the daily application of methods of freedom and equality, one that emphasises coherence between means and ends (Turcato, 2015). Before present-day neoliberalism, the specificity of anarchist organisation is not its reticular nature, which is agreed upon by mainstream organizations (Castells, 2010; Harvey, 1989), but its challenge is to be - as Malatesta stated - an organisation whose method is to guarantee its members freedom and equality in order to transform society. The shortcomings of the faith in networks, cybernetics, and self-organisation have been underscored by John Duda, who argues that 'the unquestioned belief, tragically too often demonstrated by contemporary anarchist movements, in the power and efficacy of self-organised social movements to transform the world on their own terms perhaps as owes more than we might realise to a kind of borrowed faith in scientific objectivity and technological progress, rooted in the theory of complex cybernetic systems' (Duda, 2013:70). If anarchism acknowledges mass action's spontaneity, informality and spontaneity have never been an adequate definition to portray the specificity of anarchist organisation. Thus, I would argue that neglected 'classical anarchism' brings in its tradition positive definitions of what anarchism proposes and suggestions about how anarchists should be organised, and that present scholars and militants addressing these topics should engage more with this tradition.

Contrary to the commonplaces dissociating 'order' and 'anarchism', organisation is intended, in anarchist tradition, not as a merely practical option, but as the necessary method to experiment new social relationships in daily life and to guarantee the aforementioned coherence of means and ends. This has valuable implications for how we think about organisation and activism at the present moment. There is today, in social movements, a lack of reflection on organization: without pretending to present these principles as the sole possible model, this paper aims to call militants' attention on the importance of the transparency of mandates in order to guarantee equality in decision making and to avoid the formation of new opportunistic leaderships, and at

"Organisation and formal activism: insights from the anarchist tradition", International Journal of Sociology and Social Policy, vol. 36, n. 11-12 (2006) [special number "Protest and activism (with)out organisation", edited by P. Wood and R. White], http://www.emeraldinsight.com/doi/pdfplus/10.1108/IJSSP-11-2015-0127 
the same time to practice new relations in daily struggles foreseeing the new society that these movements aim to build.

Finally, this paper has shown the role of early anarchist geographers in inspiring the concept of anarchist organisation. To understand what is called now 'prefigurative politics', coming back to the works of Reclus, Kropotkin, Fabbri, and Malatesta offers valuable insights. Their anarchist praxis can contribute much to the urgent task of creating new prefigurative anarchist geographies in the present. As Ince $(2012 ; 1653)$ argues: 'Through an emphasis on the prefigurative, it may be possible to embed within territorial practices certain organisational functions and structures that are at once effective in building spaces of struggle and developing modes of organisation that prefigure future worlds'. Finding new ways, adapted to changing realities, to shift from organised activism to the active prefiguration of new spaces and new societies is an open challenge both for anarchist/critical scholarship and for grassroots movements.

\section{References}

Bantman C. and Altena B. (2015), Reassessing the Transnational Turn: scales of analysis in anarchist and syndicalist studies, Routledge, London.

Berti G. (2003), Malatesta, l'uomo e il pensiero, Angeli, Milan.

Breitbart M. (1978), The theory and practice of anarchist decentralism in Spain, 1936-1939, PhD dissertation. Clark University: Worcester.

Castells M. (2005), "Neo-anarchism", La Vanguardia, https://groups.yahoo.com/neo/groups/anarchy_africa/conversations/messages/2733

Castells M. (2010), The rise of the network society, Wiley-Blackwell, Chichester.

CdC-FAI, 2003, “A proposito della sigla FAI", http://federazioneanarchica.org/archivio/20031228cdc.html

Cerrito G. (1973), Il ruolo dell'organizzazione anarchica, RL, Florence.

Curran G. and Gibson M. (2013), "WikiLeaks, anarchism and technologies of dissent", Antipode, Vol. 45 No. 2, pp. 294-314.

Di Paola P. (2013), The Knights Errant of Anarchy, London and the Italian anarchist diaspora (1880-1917), Liverpool University Press, Liverpool.

"Organisation and formal activism: insights from the anarchist tradition", International Journal of Sociology and Social Policy, vol. 36, n. 11-12 (2006) [special number "Protest and activism (with)out organisation", edited by P. Wood and R. White], http://www.emeraldinsight.com/doi/pdfplus/10.1108/IJSSP-11-2015-0127 
Duda J. (2013), “Cybernetics, anarchism and self-organisation”, Anarchist studies, Vol. 21, pp. $52-72$.

Fabbri L. (1907), L’organizzazione anarchica, Il Pensiero, Rome.

Fabbri L. (1951), Malatesta, l'uomo e il pensiero, RL, Naples.

Fabbri L. (1975), L'organizzazione operaia e l'anarchia, CP, Firenze (1st ed. 1906, Il Pensiero, Rome).

Fabbri L. (1998), Le influenze borghesi sull'anarchismo, Zero in Condotta, Milan.

Ferrell J. (2012), “Anarchy, geography and drift”, Antipode, Vol. 44, pp. 1687-1704.

Ferretti F. (2011), “The correspondence between Élisée Reclus and Pëtr Kropotkin as a source for the history of geography", Journal of Historical Geography, Vol. 37, pp. 216-222

Ferretti F. (2014), "Pioneers in the History of Cartography: the Geneva map collection of Élisée Reclus and Charles Perron”, Journal of Historical Geography, Vol. 43, pp. 85-95.

Ferretti F. (2016), "Reading Reclus between Italy and South America: translations of geography and anarchism in the work of Luce and Luigi Fabbri”, Journal of Historical Geography, Vol. 53, pp. $75-85$.

Gibson M. (2013), “The anarchism of the Occupy movement”, Australian Journal of Political Science, Vol. 48, pp. 335-348.

Gould S.J. (1997), “Kropotkin was no crackpot”, Natural History, Vol. 106, pp. 12-21.

Guillaume J. (1905), L'Internationale, documents et souvenirs (1864-1878), Stock, Paris.

Harvey D. (1989), The condition of postmodernity, Blackwell, Cambridge.

Hirsch S. and Van der Walt L. (Eds.) (2010), Anarchism and syndicalism in the colonial and postcolonial world, Brill, Leiden/Boston.

Il convegno nazionale della F.A.I. (2004), "L'anarchia è prioritaria, ma non si fa per posta", http://federazioneanarchica.org/archivio/20040111milano.html

Ince A. (2012) "In the shell of the old: anarchist geographies of territorialisation", Antipode, Vol. 44, pp. 1645-1666.

Kinna R. (2016), Kropotkin: Reviewing the Classical Anarchist Tradition, Edinburgh University Press, Edinburgh.

Kropotkin P. (1887), “The Coming Anarchy”, The Nineteenth Century, Vol. 126, pp. 149-154.

Kropotkin P. (1902), Mutual aid, a factor in evolution, Heinemann, London.

"Organisation and formal activism: insights from the anarchist tradition", International Journal of Sociology and Social Policy, vol. 36, n. 11-12 (2006) [special number "Protest and activism (with)out organisation", edited by P. Wood and R. White], http://www.emeraldinsight.com/doi/pdfplus/10.1108/IJSSP-11-2015-0127 
Maitron J. (1975), Le mouvement anarchiste en France, Maspero, Paris.

Malatesta E. (1897) "Anarchy and organization", The anarchist library http://theanarchistlibrary.org/library/errico-malatesta-anarchism-and-organization

Malatesta E. (1907) et al., "Anarchy and Organization: The Debate at the 1907 International Anarchist Congress", The anarchist library http://theanarchistlibrary.org/library/various-authorsanarchy-and-organization-the-debate-at-the-1907-international-anarchist-congres

Manfredonia G. (1998), "Introduzione”, in Fabbri L., Le influenze borghesi sull'anarchismo, Zero in Condotta, Milan, pp. IX-XXI.

Metchnikoff L. (1886), "Revolution and Evolution”, Contemporary Review, Vol. 50, pp. $412-$ 437.

Metchnikoff L. (1889), La civilisation et les grands fleuves historiques, Hachette, Paris.

Masini P.C. (2013), Epistolario inedito dell'internazionale: le carte della commissione di Corrispondenza dall'Archivio della Federazione Internazionale dei Lavoratori (1872-1874), Zero in Condotta, Milan.

Morris B. (2014), Anthropology, ecology and anarchism, a Brian Morris reader, PM Press, Oakland.

Peirats J. (1951), La CNT en la revolución española, Ediciones CNT, Toulouse.

Perron C. (1868), De l'obligation en matière d'instruction, Imprimerie Vaney, Geneva.

Prichard A. (2013), Justice, Order and Anarchy: The International Political Theory of PierreJoseph Proudhon, Routledge, London.

Reclus E. (1891), Évolution et révolution, Au Bureau de la Révolte, Paris.

Rossi I. (1981), La ripresa del Movimento anarchico italiano e la propaganda orale dal 1943 al 1950, RL, Pistoia.

Rossi M. (2011), Arditi non gendarmi! Dalle trincee alle barricate: arditismo di guerra e arditi del popolo (1917-1922), BFS, Pisa.

Sacchetti G. (2005), Senza frontiere : pensiero e azione dell'anarchico Umberto Marzocchi (1900-1986), Zero in condotta, Milan.

Springer S. (2011), "Public space as emancipation: meditations on anarchism, radical democracy, neoliberalism and violence", Antipode, Vol. 43, pp. 525-562.

"Organisation and formal activism: insights from the anarchist tradition", International Journal of Sociology and Social Policy, vol. 36, n. 11-12 (2006) [special number "Protest and activism (with)out organisation", edited by P. Wood and R. White], http://www.emeraldinsight.com/doi/pdfplus/10.1108/IJSSP-11-2015-0127 
Springer S. (2012), “Anarchism! What geography still ought to be”, Antipode, Vol. 44, pp. 16051624.

Springer S. (2014), "Human geography without hierarchy”, Progress in Human Geography, Vol. 38, pp. 402-419.

Springer, S., White, R., Lopes de Souza M. (Eds.) (2016), The Radicalisation of Pedagogy. Anarchism, Geography and the Spirit of Revolt, Rowman \& Littlefield, New York.

Taylor B. (2013), "From alterglobalization to Occupy Wall Street: Neoanarchism and the new spirit of the left", City, Vol. 17, pp. 729-747

Turcato D. (2007), "Italian Anarchism as a Transnational Movement, 1885-1915”, International Review of Social History, Vol. 52, pp. 407-444.

Turcato D. (2014) (Ed.), An Errico Malatesta reader, AK Press, London.

Turcato D. (2015), Making sense of anarchism: Errico Malatesta's experiments with revolution, AK Press, London.

UAI (1920), Patto d'alleanza, Bologna, http://www.fdca.it/storico/pattoalleanza.htm

Vuilleumier M. (2012), Histoire et combats : mouvement ouvrier et socialisme en Suisse, 18641960, Collège du Travail, Geneva.

Ward C. (1982), Anarchy in action, Freedom Press, London.

White R. (2009), "Explaining why the non-commodified sphere of mutual aid is so pervasive in the advanced economies", International Journal of Sociology and Social Policy, Vol. 29 Nos. 9/10, pp. 457-472

White R. and Williams C. (2012), "The pervasive nature of heterodox economic spaces at a time of neoliberal crisis: towards a 'postneoliberal' anarchist future”, Antipode, Vol. 44, No. 5, pp. $1625-1644$.

Zani R. (Ed.) (2008), Alla prova del '68. L'anarchismo internazionale al Congresso di Carrara, Zero in Condotta, Milan.

"Organisation and formal activism: insights from the anarchist tradition", International Journal of Sociology and Social Policy, vol. 36, n. 11-12 (2006) [special number "Protest and activism (with)out organisation", edited by P. Wood and R. White], http://www.emeraldinsight.com/doi/pdfplus/10.1108/IJSSP-11-2015-0127 